\title{
PENINGKATAN PENGETAHUAN PERAWAT UNTUK PERAWATAN ANAK PENDERITA KANKER
}

\author{
Sri Hartini ${ }^{1}$, Biyanti Dwi Winarsih ${ }^{2}$, Erlangga Galih Zulva Nugroho ${ }^{3}$ \\ 1,2, Program Studi Profesi Ners, ${ }^{3}$ Program Studi S1 IImu Keperawatan \\ STIKES Cendekia Utama Kudus \\ zidanina1706@gmail.com, hartini0001@yahoo.co.id, erlanggagzn@gmail.com
}

\begin{abstract}
ABSTRAK
Kanker adalah suatu penyakit yang berasal dari adanyapertumbuhan sel tubuh yang progresif dan abnormal.Sampai saat ini masih menjadi masalah kesehatan, karena merupakan salah satu penyebab utama tingginya angka kematian yang berkisar 8,2 juta orang sedangkan pada tingkat nasional angka kematian kanker berkisar 5,7 \% dari keseluruhan kasus kematian. Kanker dan berbagai pengobatan yang dilakukan, memberikan efek samping yang berhubungan dengan permasalahan fisik \&psikologi. Kanker pada anak yang diobati dengan terapi kombinasi, seperti pembedahan, radioterapi, dan kemoterapi umumnya menimbulkan berbagai efek samping. Kondisi ini jika tidak ditangani dengan baik akan memperburuk kesehatan pasien kanker dan menyebabkan penurunan kualitas hidupnya. Perawatanak harus dapat memberikan asuhan keperawatan yang tepat terutama terkait adaptasipasienanak agar bisa bertahan dari kondisi penyakit.
\end{abstract}

Kata Kunci : Pengetahuan, kanker, anak, perawat anak.

\begin{abstract}
Cancer disease that originates from the progressive and abnormal growth of body cells. Until now it is still a health problem, because it is one of the main causes of the high death rate which is around 8.2 million people while at the national level the cancer mortality rate is around $5.7 \%$ of all death cases. Cancer and various treatments carried out, providing side effects associated with physical \& psychological problems. Cancer in children treated with combination therapy, such as surgery, radiotherapy, and chemotherapy generally causes various side effects. This condition if not treated properly will worsen the health of patients and cause a decrease in the quality of life. Pediatric nurses must be able to provide appropriate nursing care, especially related to adaptation of pediatric patients in order to survive the condition of the disease.
\end{abstract}

Keywords: Knowledge, Cancer, Pediatric, Pediatric Nursing 


\section{PENDAHULUAN}

Kanker didefinisikan sebagai suatu penyakit yang berasal dari adanyapertumbuhan sel tubuh yang progresif dan abnormal. Kondisi ini disebabkanolehterjadinya perubahan pada deoxiribonucleid acid (DNA), sehingga sel kehilangan fungsinya secara normal. Pertumbuhan sel kanker akan berlangsung cepat dan mendesak sel normal tubuh, sistem pembuluh darah serta organ vital lainnya sehingga menghasilkan berbagai gejala (James, dkk, 2013). Tandadangejalaadanya penyakit kanker tergantung dari jenis kanker, lokasi pada tubuh, luasnya dan umur anak. Bila sel kanker ini sudah menyebar (metastasis) dan menginfiltrasi organ tubuh yang lain maka menyebabkan hilangnya fungsi organ secara progresif dan dapat berakhir dengan kematian (Ball, dkk, 2010).

Kanker sampai saat ini masih menjadi masalah kesehatan, karena merupakan salah satu penyebab utama tingginya angka kematian yang berkisar 8,2 juta orang (WHO, 2014), sedangkan pada tingkat nasional angka kematian kanker berkisar 5,7\% dari keseluruhan kasus kematian (Kemenkes RI, 2014). Menurut data dari GLOBOCAN, IARC pada tahun 2012 terdapat 14.067 .894 kasus baru kanker pada tingkat dunia. Data dari Riskesdas Kemenkes RI padatahun2013, penyakit kanker di Indonesia memiliki prevalensi berkisar 1,4 per 1000 penduduk atau sekitar 347.792 penduduk dan menduduki peringkat ke 7 dari seluruh penyebab kematian.

Berdasarkan data dari IARC (International Agency ofResearch Cancer), $80 \%$ anak yang terdiagnosa kankerterletak di negara berkembang, dan Indonesiamerupakan salah satunya. Jumlah anak penderitakanker di negara berkembang ini semakin meningkattiap tahunnya.Terdapat 11.000 kasus kanker pada anak setiap tahunnya dan sepertiga dari kanker anak adalah leukemia (Kemenkes RI, 2015). Menurut Marcdante, Kliegmen, Jenson, dan Behrhman (2011), jenis kanker yang tersering pada anak adalah leukemia dan limfoma, kemudian diikuti dengan tumor otak/susunan saraf pusat, sarcoma jaringan lunak, dan kanker tulang. Banyak tanda dan gejala kanker bersifat non spesifik, 
namun sebagian besar anak dengan penyakit kanker menunjukkan gejala demam, kelelahan dan anoreksia.

Berbagai pilihan terapi bisa dilakukan untuk pengobatan kanker, diantaranya operasi, radioterapi, kemoterapi dan beberapa metode terapi lainnya. Dari berbagai macam pilihan terapi untuk kanker, pengobatan dengan kemoterapi menjadi pilihan paling sering digunakan. Kemoterapi digunakan untuk terapi kanker sistemik dan kanker dengan metastasis klinis ataupun subklinis. Hingga saat ini obat anti kanker jenis kemoterapi yang sudah dapat digunakan secara klinis mencapai 70 jenis lebih dan sudah lebih dari 10 jenis kanker yang dapat disembuhkan dengan kemoterapi, atau sekitar $5 \%$ dari seluruh pasien kanker. Jumlah ini hampir setara dengan $10 \%$ dari angka kematian akibat kanker setiap tahun, termasuk kanker dengan derajat keganasan tinggi. Pada sebagian kanker lainnya, meskipun tidak dapat disembuhkan dengan kemoterapi, namun lama harapan hidupnya dapat diperpanjang (Doesen, 2008).

Kanker dan berbagai pengobatan yang dilakukan, memberikan efek samping yang berhubungan dengan permasalahan fisik \&psikologi. Menurut Barron dan Pencharz (2007), sebagian besar kanker pada anak yang diobati dengan terapi kombinasi, seperti pembedahan, radioterapi, dan kemoterapi umumnya menimbulkan berbagai efek samping, yang dapat menyebabkan seorang anak berada dalam keadaan kurang gizi. Pengobatan radiasi pada pasien kanker dapatmenimbulkan berbagai efek pada saluran cerna. Radiasi pada thorax dapat menimbulkan dysphagia atau gangguan menelan. Radiasi pada daerah abdomen dapat menyebabkan terjadinya malabsorbsi zat-zat gizi, gastritis, nausea, vomiting, diare yang selanjutnya dapat merusak bagian lain dari saluran pencernaan.Sedangkangejala-gejala gangguan psikologis yang bisa muncul pada pasien anak yang sudah mengalami kanker adalah kemarahan, kecemasan, depresi, dan tidak mempunyai harapan. Kondisi ini jika tidak ditangani dengan baik akan memperburuk kesehatan pasien kanker dan menyebabkan penurunan kualitas hidupnya. Harapan hidup 
pasien lebih pendek apabila mengalami gangguan psikiatrik dibandingkan dengan yang mampu mengatasi kondisi tersebut (Kurniawati, 2015).

Dalam menghadapi penyakit kronik seperti kanker, tenagamedisterutamaperawatanak harus dapat memberikan asuhan keperawatan yang tepat terutama terkait adaptasipasienanak agar bisa bertahan dari kondisi penyakit. Sebagaiseorangperawatanak dituntut untuk bisa membantu meningkatkan mekanisme koping pasien\&mampumemberikansolusiterkaitberbagaipermasalahanfisik yang muncul agar mampu beradaptasi dengan kondisi sakitnya, sehingga pasien mampu mempertahankan integritas dirinya. Perawatan pada pasien kanker pada anak ini tergolong sebagai bentuk perawatan paliatif yang merupakan bentuk pelayanan yang bertujuan memperbaiki kualitas hidup pasien dan keluarga dari penyakit yang dapat mengancam jiwa, melalui pencegahan dan peniadaan dengan cara identifikasi dini, penilaian yang tertib, penanganan nyeri dan masalah-masalah lain yaitu fisik, psikososial dan spiritual (llham, dkk, 2019).

Perawatan paliatif sangat dibutuhkan oleh pasien yang mengalami penyakit yang tidak dapat disembuhkan lagi. Perawatan paliatif sesuai untuk semua pasien dengan diagnosis kondisi yang mengancam nyawa. Layanan perawatan paliatif paling efektif ketika diintegrasikan ke dalam layanan perawatan yang spesifik (seperti rumah sakit, perawatan rumah, bantuan hidup, panti jompo, dan sebagainya). Hal ini membutuhkan pelatihan dasar perawatan paliatif untuk praktisi di segala bidang dalam layanan primer, seperti dengan membuat pola rujukan dan akses untuk perawatan spesialis paliatif dan tim perawatan paliatif formal (Champbell, dkk, 2014). Pentingnya tingkat pengetahuan perawat anak dalam menangani dan memberikan asuhan keperawatan pasien kanker anak akan berpengaruh pada keberhasilan dalam penanganan permasalahan baik fisik maupun psikologis. 


\section{METODE PELAKSANAAN}

Kegiatan pengabdian ini menggunakan metode ceramah, Tanya jawab dan demonstrasi. Dalam memberikan materi menggunakan metode ceramah tentanga perawatan $\mathrm{Ca}$ pada anak. Langkah-langkah yang digunakan dalam pelaksanaan pengabdian ini ini adalah sebagai berikut

1. Langkah 1

Pengabdi melakukan proses perijinan di RS setempat dengan membawa surat tugas dari Ketua STIKES Cendekia Utama Kudus

2. Langkah 2

Pengabdi melakukan sosialisasi terkait kegiatan pengabdian kepada perawatan ruangan khusus anak

3. Langkah 3

Pengabdi melakukan skrining pengetahuan dan kemampuan tentang perawatan anak dengan $\mathrm{Ca}$

4. Langkah 4

Pengabdi dan perawatan melakukan simulasi tentang tehnik komunikasi dan konseling tentang perawatan cancer

5. Langkah 5

Pengabdi melakukan evaluasi proses dan bertanya kepada peserta

6. Langkah 6

Pengabdi memberikan rencana dan program tindak lanjut kepada kepala ruang bangsal anak

\section{HASIL DAN PEMBAHASAN}

Kegiatan pengabdian pada masyarakat tentang perawatan paliatif pada pasien kronis. Kader pemahaman paliatif care. Peserta tidak dipungut biaya dan pengabdi sebagai nara sumber tidak mendapatkan honor atas tugas yang telah dilakukan.

Secara garis besar hasil kegiatan yang telah tercapai dalam pengabdian masyarakat ini adalah sebagai berikut : 
1. Materi yang disampaikan dapat diterima dan dapat dipahami, serta mendapat respon dari peserta yang ditandai dengan adanya pertanyaan-pertanyaan yang muncul

2. Secara umum peserta memahami dan mampu mengaplikasikan perawatan cancer pada anak

Kegiatan pengabdian masyarakat di RSUD dr. Loekmonohadi Kudus mendapatkan respon baik dan perawat sangat antusias. Secara umum hasil pengabdian meliputi beberapa aspek pencapaian yaitu :

1. Ketercapaian tujuan kegiatan

Ketercapaian tujuan kegiatan pengabdian masyarakat tentang peningkatan kemampuan perawat dalam memahami perawatan $\mathrm{Ca}$ pada anak (paliatif) dengan benar sudah baik, semua persiapan dan materi yang direncanakan dapat tersapaikan dan didukung dengan hasil pembuktian evidence based yang dilakukan pengabdi secara langsung.

2. Ketercapaian target materi yang direncanakan

Ketercapaian target materi pada kegiatan pengabdian masyarakat ini cukup baik, karena materi telah dapat disampaikan secara keseluruhan.

3. Kemampuan peserta dalam menguasai materi

Kemampuan peserta dilihat dari pemahaman perawatan cancer(paliatif) yang diberikan oleh narasumber. Aplikasi perawatan Cancer (paliatif) di tingkat perawat anak nantinya akan disosialisasikan kemasyarak yang anaknya terkena $\mathrm{Ca}$.

Pelaksanaan kegiatan pengabdian pada masyarakat terdapat faktor pendukung dan penghambat kegiatan pengabdian pada masyarakat:

1. Faktor pendukung 
a. Adanya respon positif dari pihak Rumah sakit dan Perawat dalam pelaksanaan kegiatan sosilaisasi perawatan anak dengan $\mathrm{Ca}$ (paliatif)

b. Tersedianya sarana yang baik

2. Faktor penghambat

Dalam pelaksanaan kegiatan evaluasi tidak dapat dilakukan untuk pendampingan perawat anak untuk kunjungan ke rumah warga secara keseluruhan mengevaluasi pemahaman perawatan anak $\mathrm{Ca}$ ini dikarenakan kurangnya waktu dan tenaga.

\section{SIMPULAN DAN SARAN}

\section{Simpulan}

Pelaksanaan pengabdian masyarakat dalam rangka meningkatkan kemampuan perawat rumah sakit dalam pemahaman kasus kasupenyakit kronis yang mengarah pada perawatan paliatif dapat disimpulkan berhasil sampai tahap kemampuan untuk mengaplikasikan. Keberhasilan ini ditunjukkan antara lain oleh:

1. Adanya kesesuaian materi dalam mengatasi masalah di Rumah sakit dimana perawat khususnya keluarga dengan kasus-kasus penyakit kronik dan penyakit terminal mampu memahami dan mengaplikasikan perawatan paliatif di rumah

2. Adanya respon yang positif dari peserta khususnya perawat ruang anak yang ditunjukkan dengan pertanyaan dan tanggapan yang diberikan selama pengabdian

3. Sebagian besar $(90 \%)$ peserta perawat anak nilainya meningkat dari nilai pre tes dengan post test .

\section{Saran}

1. Bagi perawat

Perlu adanya kegiatan untuk memperluas wawasan terkait pengembangan intervensi keperawatan khususnya untuk mengatasi 
masalah yang terjadi di masyarakat. Dapat berupa peningkatan pengetahuan dan kemapuan perawat dalam edukasi nantinya pada masyarakat atau keluarga dalam melakukan upaya preventif penyakit kronis dan kasus paliatif

2. Bagi Rumah sakit

Perlu adanya perhatian yang serius dalam upaya pencegahan penyakit dalam masyarakat

\section{UCAPAN TERIMA KASIH}

3. Ketua Lembaga Penelitian dan Pengabdian Masyarakat dan Ketua Program Studi S1 IImu Keperawatan/Ners STIKES Cendekia Utama Kudus yang telah memberikan arahan dan memfasilitasi kegiatan.

4. Direktur RSUD dr. Loekmonohadi Kudus dan Kepala Ruang beserta Perawat Ruang Rawatanak.

\section{DAFTAR PUSTAKA}

1. Doyle, D, Hanks, G \& MacDonald, N, 1999, Oxford textbook of Palliative Medicine, 2nd edn, Oxford University Press, Oxford

2. Goldman, 2006, Oxford Textbook of Palliative care of Children., pp 313. New York. Oxford University Press,

3. Palliative Expert Group, 2005, Therapeutic Guidelines Palliative Care, version 2, Therapeutic Guideline Limited, Melbourn

4. Twycross, R \& Wilcock A, 2001, Symptom Management in Advanced Cancer, 3rd edn, Radcliffe Medical Press, Oxon

5. Vella-Brincat, J, Macleod, A.D, MacLeod, R, 2008, The Palliative Care Handbook, Guidelines for Clinical mnanagement and Symptom Control, 4th edn, The Caxton Press, Auckland.

6. WHO, 2007. WHO guide for effective programmes: Palliative Care. ed. Geneva, World Health Organization 
7. Woodruff, R, 1999, Palliative Medicine Symptomatic and Supportive Care for Patients with Advanced Cancer and AIDS, 3rd edn, Oxford University Press, Melbourne.

8. Irvin, H. 2001, Palliative care in Cancer in Children, Clinical Management. Oxford: University Press

9. Goldman, Ann; Haiin, Richard; Liben, Stephen. 2006, Oxford Textbook of Palliative Care for Children.. Oxford: University Press 